\title{
Enhanced oral bioavailability of Paclitaxel in presence of P-gp blockers: Smart extraction procedure, antitumor and side effects study in mice
}

\author{
Mona M. Kamal ${ }^{1 *}$, Mohamed T. Khayyal' ${ }^{2}$, Mahmoud M. Merzabani ${ }^{3}$, Abdel Moneim M. Osman ${ }^{3}$, Yasmin M. \\ Attia $^{3}$, Magda M. F. Ismail ${ }^{4}$ \\ ${ }^{1}$ Department of Pharmacology, Faculty of Pharmacy, Al-Azhar University, Cairo, Egypt \\ ${ }^{2}$ Department of Pharmacology, Faculty of Pharmacy, Cairo University, Cairo, Egypt \\ ${ }^{3}$ Department of Pharmacology, National Cancer Institute, Cairo University, Cairo, Egypt \\ ${ }^{4}$ Department of pharmaceutical Chemistry, Faculty of Pharmacy, Al-Azhar University, Cairo, Egypt \\ * Correspondence: Email: monamohammed@azhar.edu.eg
}

Article history: Received: 24-03-2021

Revised:31-05-2021

Accepted: 18-08-2021

\begin{abstract}
Taxanes (Paclitaxel) and other microtubule-stabilizing operators include a vital lesson of anticancer drugs particularly ovarian and breast carcinoma. Since of its destitute bioavailability, the medication is ordinarily given by I.V. implantation, defined in a blend of Cremophor EL and ethanol (1:1, $\mathrm{v} / \mathrm{v}$ : paclitaxel). Verbal bioavailability of Paclitaxel may be improved by the co-administration of Cyclosporine and Verapamil as P-gp efflux pump blockers. Rh-123, a backhanded file of P-gp transport was utilized to degree the P-gp efflux pump movement within the intestinal divider likes Paclitaxel. The measured fluorescence of Rh-123 detected spectrofluorometrically represented the amount of Paclitaxel in the intestinal cells under the influence of the P-gp blocking drugs. The results showed that dichloromethane (DCM) was the most efficient organic solvent to extract paclitaxel from the plasma samples with a recovery of almost $100 \%$. The verbal bioavailability of paclitaxel was improved 2.7 overlays by verapamil, and up to 5.7 crease by cyclosporine, appearing that both drugs successfully restrained the P-gp pump within the intestinal tract, permitting for way better retention of paclitaxel. Concerning the antitumor action of Paclitaxel, both Cyclosporine and Verapamil did not unfavorably influence the antitumor action of Paclitaxel in tumor-bearing mice, whereas Cyclosporine appeared 4.3 days delay in tumor development compared to control untreated mice. Additionally, toxicity parameters such as leukocytes count, serum level of LDH and CK were investigated to ensure that the enhanced absorption of Paclitaxel does not aggravate its toxicity.
\end{abstract}

Keywords: Paclitaxel, extraction, oral bioavailability, P-gp blockers, antitumor, histopathology, toxicity.

This is an open access article distributed under the CC BY-NC-ND license https://creativecommons.org/licenses/by/4.0/

\section{INTRODUCTION}

Paclitaxel (Taxol) is an antineoplastic utilized to treat numerous sorts of cancer, particularly ovarian and breast carcinoma ${ }^{1}$. Paclitaxel caused absconds in mitotic axle get together, chromosome isolation, and cell division. It pieces the movement of mitosis and delayed enactment of the mitotic checkpoint triggers apoptosis or inversion to the G0-phase of the cell cycle without cell division ${ }^{2,3}$. Since of its destitute verbal assimilation and subsequently destitute bioavailability by this course, the sedate is more often than not given by intravenous mixture, defined in a blend of Cremophor EL and ethanol (1:1, v/v: paclitaxel) ${ }^{4,5}$. The destitute verbal bioavailability comes about primarily from the movement of the Pglycoprotein (P-gp) efflux pump multi-drug transporter ${ }^{5,6}$.

P-glycoprotein (P-gp), a transmembrane porousness glycoprotein, is portion of ATP authoritative cassette superfamily which plays a key part in transporting drugs out the cells. It exists in numerous organs within the body and has wide extend of substrates. The pump acts to diminish the intracellular aggregation of drugs by extruding xenobiotics from the cell. Thus, focusing on P-gp was utilized to turn around multidrug resistance and progress destitute bioavailability disadvantages. A number of pharmacologic operators counting cyclosporine (an immunosuppressive medicate), 
verapamil (a calcium channel blocker), tamoxifen, quinidine and phenothiazine have been shown up to limit P-glycoprotein ${ }^{7,8}$. Verapamil and cyclosporine are the foremost broadly characterized inhibitors of P-glycoprotein and were the primary multidrug resistance (MDR)-reversal operators that come to clinical trial ${ }^{9,10}$. The reason of this ponder is to improve the bioavailability of paclitaxel after verbal organization through the utilize of $\mathrm{P}$-gp blockers such as Cyclosporine and Verapamil.

Until as of late, there has been no inquire about that clearly depicted the quantitative profile of $\mathrm{P}$ glycoprotein restraint. These results prompted us to start a comprehensive analysis that determines the efficacy of P-gp inhibitors to increase the absorption of paclitaxel from the gut lumen by using a smart extraction procedure using HPLC technique.

In an endeavor to create more secure clinical details, the parameters investigated in this study: pharmacokinetic parameters of paclitaxel after i.p. and p.o. administration with or without P-gp blockers. Moreover, the anti-tumor activity of paclitaxel after P-gp blockers co-administration will be evaluated. Finally, toxicity examination through total leucocyte count, cardiac toxicity study and LDH, and CK-MB count will be determined.

\section{METHODS}

Animals: this ponder was carried out utilizing female Swiss albino mice weighing 20-25g, obtained from the animal house of the National Cancer Institute (NCI), Cairo University, Egypt. Animals were housed in plastic cages and kept at a steady temperature of $22^{\circ} \mathrm{C} \pm 2{ }^{\circ} \mathrm{C}$ and constant humidity. They were permitted free get to a standard pellet slim down and water.

Drugs: Paclitaxel (Taxol) was obtained from Bristol - Myers Squibb (Princeton, USA). It was supplied in $5 \mathrm{ml}$ vials, each $\mathrm{ml}$ containing $6 \mathrm{mg}$ paclitaxel and 527 $\mathrm{mg}$ of Cremophor EL (Polyoxyethylated castor oil) and $49.7 \%$ (v/v) dehydrated alcohol. Cyclosporine (Sandimmun) was obtained from Novartis Pharma AG (Basel, Switzerland). It was supplied in $1 \mathrm{ml}$ vials; each $\mathrm{ml}$ contains $50 \mathrm{mg}$ cyclosporine A in Cremophor EL-ethanol (67.1:32.9, v/v). Verapamil (Isoptin) was obtained from Arab Drug Co., Egypt. Each ampoule (2 ml) contains $5 \mathrm{mg}$ verapamil hydrochloride.

Chemicals and Solutions: All chemicals and solutions were HPLC grade. Acetonitrile, Ethylenediamine tetra-acetic acid disodium salt, dehydrate, Rhodamin 123 and phosphate buffered saline were purchased from Sigma Chemical Co. (St. Louis, MO, USA). Dichloromethane was purchased from BDH Chemicals Ltd., (England). Eosin dye is prepared by dissolving $3 \mathrm{mg}$ eosin powder (E. Merck, Darmstadt, Germany) in $100 \mathrm{ml}$ of $80 \%$ ethanol, then $5 \mathrm{ml}$ acetic acid were added and the solution was filtered and used as a stain for the histopathology of heart specimens ${ }^{11}$. Formalin: (Formaldehyde 40\%) was brought from Gainland Chemical Company (Flintshire. UK).

Statistical methods: Pharmacokinetic parameters were calculated according to non-linear kinetics using the software package TopFit (Version 2). All results values were expressed as mean of six animals' \pm SE. using one way ANOVA followed by Duncan test at $p$ $\leq 0.05$ and paired $-\mathrm{t}$-test for each two independent groups using excel program

\subsection{Pharmacokinetic Study}

Animals were divided into 4 groups as follows: Group 1: given paclitaxel $(10 \mathrm{mg} / \mathrm{kg})$ intraperitoneally in a single dose. Group 2: given paclitaxel $(10 \mathrm{mg} / \mathrm{kg})$ orally in a single dose. Group 3: given verapamil $(20 \mathrm{mg} / \mathrm{kg})$ intraperitoneally once daily for three successive days. On the $4^{\text {th }}$ day, paclitaxel $(10 \mathrm{mg} / \mathrm{kg})$ was given orally. Group 4: injected intraperitoneally with cyclosporine (50 $\mathrm{mg} / \mathrm{kg}$ ), once daily for three successive days. On the $4^{\text {th }}$ day paclitaxel $(10 \mathrm{mg} / \mathrm{kg})$ was given orally. Animals (in groups of 6 at each time point) treated with paclitaxel orally were subsequently sacrificed at the following time intervals: $0.5,1,2,4,8,12$ and 24 hours (Groups 2, 3 and 4), while those receiving the drug parenterally were sacrificed at $0.25,0.5,1,2,4$, 8,12 and 24 hours after paclitaxel injection (Group1). Upon sacrificing the animals, blood was withdrawn in heparinized tubes and plasma was separated by centrifugation at $3000 \mathrm{rpm}$ for $10 \mathrm{~min}$, and stored at $20^{\circ} \mathrm{C}$ until analyzed by HPLC as described below.

HPLC analysis of Paclitaxel

Dichloromethane was routinely used to extract paclitaxel from the plasma samples where eight hundred $\mu 1 \mathrm{DCM}$ were added to $200 \mu \mathrm{l}$ plasma sample, mixed vigorously for 5 min using a Vortex shaker, followed by centrifugation for $10 \mathrm{~min}$ at 3000 rpm. Organic layer was transferred to a new glass tube. Residue was then dissolved in $1 \mathrm{ml}$ of the mobile phase (acetonitrile: distilled $\mathrm{H}_{2} \mathrm{O} 1: 1 \mathrm{v} / \mathrm{v}$ ) and $20 \mu \mathrm{l}$ were injected into the HPLC system. In each run, a separate plasma standard curve was prepared with each set of samples. HPLC system consisted of a model 322 pump (Kontron, Italy) and SP560 autosampler (Biotek, Italy). The chromatographic separation was conducted on a $10 \mu \mathrm{m}$ Hypersil ODS 4.6 X250 mm column (Hewlett Packard Co, San Fernando, CA). The mobile phase was used at a flow 
rate of $2 \mathrm{ml} / \mathrm{min}$. Peaks were monitored at $228 \mathrm{~nm}$ on a Waters (Model 490) programmable multi-wave length detector ${ }^{12}$.

Pharmacokinetic analysis: pharmacokinetic parameters were calculated by non-compartmental methods using the software package TopFit (Version 2). The area under the plasma concentration-time curve of paclitaxel i.p. (AUC i.p.) and paclitaxel p.o. (AUC p.o.) were calculated by linear trapezoidal rule without extrapolation to infinity using the same software package. The maximum plasma concentration $\left(\mathrm{C}_{\max }\right)$ and the time to reach the maximum plasma concentration $\left(\mathrm{T}_{\max }\right)$ were determined by a visual inspection of the experimental data. The elimination rate constant $\left(\mathrm{k}_{\mathrm{el}}\right)$ was calculated by regression analysis from the slope of the terminal part of the concentration-time curve, and the half-life $\left(\mathrm{t}_{1 / 2}\right)$ of the drug was obtained by $693 / \mathrm{k}_{\mathrm{el}}$. The oral bioavailability $(\mathrm{F})$ was calculated using the formula: $\quad \mathrm{F}=$ [AUC p.o. / AUC i.p.] $\times 100 \%$. Assay of $P-g p$ using rhodamine-123

The method used is a slight modification of that described by Ludescher et al (1991) ${ }^{13}$ and depends on measuring the fluorescence of rhodamine-123 dye which is transported by the membrane efflux pump, $\mathrm{P}$-gp. The procedure used measures the accumulation of the dye in the tissue. The small intestine was dissected and immersed immediately in ice-cold saline, then evacuated from its contents by perfusion with saline. The cleaned intestine was then blotted dry on filter paper. About $2 \mathrm{~cm}$ length of the small intestine was cut into very small pieces on glass slide then weighed. Phosphate buffered saline was added to the cut tissue $(1: 5, \mathrm{wt} / \mathrm{v})$ followed by $(200 \mathrm{ng} / \mathrm{ml})$ rhodamine. The mixture was then incubated in a shaking water bath at $37{ }^{\circ} \mathrm{C}$ for 2 hours and the samples were centrifuged at $2000 \mathrm{rpm}$ for $5 \mathrm{~min}$. The supernatant was decanted and the tissue pellets washed twice with ice-cold phosphate buffered saline for $5 \mathrm{~min}$. centrifugation after each addition. Tissue pellets were then re-suspended in distilled water $(20$ $\%$ ) and incubated in a shaker water bath at $37^{\circ} \mathrm{C}$ for 2 hours to allow for rupturing of the cells which retained rhodamine-123. Afterward, tissue pellets were centrifuged at $2000 \mathrm{rpm}$ for $5 \mathrm{~min}$. The fluorescence intensity of effluxed rhodamine-123 was determined spectrofluorometrically (SFM 25 Kontron, Italy) in the supernatant using excitation and emission wave lengths 470 and $590 \mathrm{~mm}$, respectively.

\subsection{Ehrlich Ascites Carcinoma (EAC) Cells}

A line of Ehrlich ascites carcinoma has been used throughout this work was supplied through the courtesy of Dr. G. Klein, Amsterdam, and Holland. The tumor line was maintained in the Cancer Institute in female Swiss albino mice by weekly i.p. transplantation of $0.25 \times 10^{6}$ cells. EAC cells were suspended in normal saline to obtain a concentration of $0.25 \times 10^{6} \mathrm{EAC}$-cells $/ \mathrm{ml}$. Then, $0.2 \mathrm{ml}$ of the cell suspension was inoculated subcutaneously in the right thigh of each of 50 female Swiss albino mice. Mice with palpable tumor mass $\left(100 \mathrm{~mm}^{3}\right)$ that developed within 7 days after tumor implantation were divided at random into 5 groups of 10 animals each as indicated in the experimental design. The change in tumor size was measured every other day and up to 30 days post treatment using a Vernier caliper (Tricle Brand, Shanghai, China). The tumor volume was calculated by the following formula according to Tumor volume $\left(\mathrm{mm}^{3}\right)=\left[4(\mathrm{~A} / 2)^{2} \times(\mathrm{B} / 2)\right] / 3,1$ Papadopoulos et al. (1989) ${ }^{16}$, where A and B denote the minor and major tumor axis respectively. Tumor growth delay (TGD) was then calculated as the additional days for each individual treated tumor to reach $2500 \mathrm{~mm}^{3}$ beyond that of the control group. The percentage of inhibition of tumor growth was calculated at days 2, 10, 16, 22 and 28 from inoculation of the Ehrlich cells.

\subsection{Toxicological study}

\subsubsection{Total white blood cell count}

To count the number of white blood cells in a sample of whole heparinized blood, the red cells have first to be lysed by means of a "diluting" fluid that also denatures the nuclear proteins of the leucocytes and makes their different nuclear characteristics readily identifiable ${ }^{14}$. White cell diluting fluid: Glacial acetic acid $(2 \mathrm{ml}), 1 \%$ Methylene blue (2 drops) in $98 \mathrm{ml}$ of distilled water. A $20 \mu \mathrm{l}$ aliquot of blood was added to $0.38 \mathrm{ml}$ diluting fluid (dilution $1: 20$ ) in a small capped tube. The tube was mixed well by hand for $2 \mathrm{~min}$. A Neubauer counting chamber was smoothly filled and the chamber was placed in a moistened Petri dish for $2 \mathrm{~min}$. All the blue stained leucocytes in an area of $4 \mathrm{~mm}^{2}$ were counted. Total white blood cell count per $\mathrm{ml}=\mathrm{N}$ x 50 x 1000, where $\mathrm{N}=$ total count in $20 \mu \mathrm{l}$ and 50 is the dilution factor.

\subsubsection{Determination of serum lactate} dehydrogenase $(\mathrm{LDH})$.

$\mathrm{LDH}$ stimulates the oxidation of lactate to pyruvate, following reduction of NAD to NADH [17]. LDH was measured using kit brought from Stanbio Laboratory Inc. (San Antonio, TX., USA). For each serum sample to be measured, cuvettes had to be prefilled with reconstituted $\mathrm{LDH}$ reagent $(1.0 \mathrm{ml})$ and warmed to $37^{\circ} \mathrm{C}$ for $3 \mathrm{~min}$. Then, $0.025 \mathrm{ml}$ serum was added to its respective cuvette, mixed well and incubated for $1 \mathrm{~min}$ at $37^{\circ} \mathrm{C}$. The wavelength of the instrument (Photometer 4010Boehringer, Mannheim, Germany) was set at $340 \mathrm{~nm}$ and distilled water was used as blank. The increase in absorbance at 60 seconds intervals $(\Delta \mathrm{A} / \mathrm{min})$ was recorded for $3 \mathrm{~min}$. $\mathrm{LDH}$ activity was calculated as international units per liter according to the following equation: $\mathrm{LDH}$ activity $(\mathrm{U} / \mathrm{L})=[(\Delta \mathrm{A} / \mathrm{min}) /($ Absorptivity $)] \times[($ Total 
volume $) /($ Sample volume $)]$

$$
=\left[\begin{array}{llll}
(\Delta \mathrm{A} / \mathrm{min}) / & (0.00622)] & \mathrm{x} & {[(1.025) /}
\end{array}\right.
$$

$(0.025)]$

$$
=[\Delta \mathrm{A} / \mathrm{min}] \times 6592
$$

[The absorptivity micromolar extinction coefficient of NADH at $340 \mathrm{~nm}$ has a value of 0.00622$]$.

\subsubsection{Determination of serum creatine kinase -MB $(\mathrm{CK}-\mathrm{MB})$}

To measure CK-MK level according to the author's instruction ${ }^{15}$ using kit from Stanbio Laboratory Inc. (San Antonio, TX., USA). $1 \mathrm{ml}$ of CK reagent was added into a cuvette/test tube and warmed for approximately $5 \mathrm{~min}$ at $37{ }^{\circ} \mathrm{C}$ for each sample. Fifty $\mu l$ of the sample added to its respective tube, mixed well and then further incubated for $5 \mathrm{~min}$ at 37 ${ }^{0} \mathrm{C}$. The wave length of the spectrophotometer (4010Boehringer Mannheim, Germany), was set at $340 \mathrm{~nm}$. Deionized water was used as blank. After $5 \mathrm{~min}$ had elapsed, the increase in absorbance $(\Delta \mathrm{A} / \mathrm{min})$ was recorded.

CK-B activity $(\mathrm{U} / \mathrm{L})=(\Delta \mathrm{A} / \mathrm{min}) \times 3376$

CK-MB activity (U/L) = CK-B activity (U/L) x 2

\subsubsection{Histopathological examination:}

Tissue sections for histopathology were fixed in $10 \%$ neutral buffered formalin for 24 hours, and paraffin blocks were prepared. Five micron thick sections were obtained from blocks and stained by routine hematoxylin and eosin stain.

\section{RESULTS}

\subsection{Pharmacokinetic parameters of paclitaxel with or without P-glycoprotein blockers in mice plasma}

Intraperitoneal administration of paclitaxel (10 $\mathrm{mg} / \mathrm{Kg})$ showed a peak plasma level $\left(\mathrm{C}_{\max }\right)$ of 1.51 $\mu \mathrm{g} / \mathrm{ml}$, and an AUC $=16.17 \mu \mathrm{g} . \mathrm{hr} / \mathrm{ml}$, whereas oral administration of the same dose had very much lower values $\left(\mathrm{C}_{\max }=0.21 \mu \mathrm{g} / \mathrm{ml}\right.$ and $\left.\mathrm{AUC}=1.52 \mu \mathrm{g} . \mathrm{hr} / \mathrm{ml}\right)$. The oral bioavailability of paclitaxel was $9.4 \%$ taking the intraperitoneal value as $100 \%$ (Table 1).

Pharmacokinetic parameters were calculated according to non-linear kinetics using the software package TopFit (Version 2).

Prior administration of paclitaxel with cyclosporine (given in a dose of $50 \mathrm{mg} / \mathrm{Kg}$ I.P. for 3 successive days prior to P.O. paclitaxel treatment) enhanced the bioavailability of orally administered paclitaxel, reaching a value of $54.4 \%$. The AUC was also increased to $8.79 \mu \mathrm{g} . \mathrm{hr} / \mathrm{ml}$ (Table 1). Prior administration of paclitaxel with verapamil (given in a dose of $20 \mathrm{mg} / \mathrm{Kg}$ I.P. for 3 successive days prior to P.O. paclitaxel) increased the bioavailability of Paclitaxel to $25.3 \%$ and the AUC of Paclitaxel to 4.09 $\mu \mathrm{g} . \mathrm{hr} / \mathrm{ml}$ (Table 1). The plasma concentrationstime curves of oral or intraperitoneal paclitaxel with or without P-glycoprotein blockers are shown in Figure (1)

Table 1: Pharmacokinetic parameters of paclitaxel with or without P-glycoprotein blockers

\begin{tabular}{ccccc}
\hline $\begin{array}{l}\text { Pharmacokinetic } \\
\text { parameters }\end{array}$ & i. p. & p. o. & $\begin{array}{c}\text { p.o+ } \\
\text { Ver. }\end{array}$ & $\begin{array}{c}\text { p.o+ } \\
\text { Cyc. }\end{array}$ \\
\hline $\mathbf{C}_{\max }(\boldsymbol{\mu g} / \mathbf{m l})$ & 1.51 & 0.21 & 0.534 & 0.74 \\
\hline $\mathbf{T}_{\max }(\mathbf{h r})$ & 0.25 & 2 & 2 & 2 \\
\hline $\mathbf{t}_{\mathbf{1} / \mathbf{2}}(\mathbf{h r})$ & 5.49 & 1.87 & 2.03 & 6.8 \\
\hline $\mathbf{k e}(\mathbf{1} / \mathbf{h r})$ & 0.126 & 0.371 & 0.341 & 0.102 \\
\hline $\begin{array}{c}\text { AUC 0-24 hr } \\
(\boldsymbol{\mu g . h r} / \mathbf{m l})\end{array}$ & 16.17 & 1.52 & 4.09 & 8.79 \\
\hline $\begin{array}{c}\text { Oral } \\
\text { bioavailability (F) }\end{array}$ & $100 \%$ & $9.4 \%$ & $25.3 \%$ & $54.4 \%$ \\
\hline
\end{tabular}

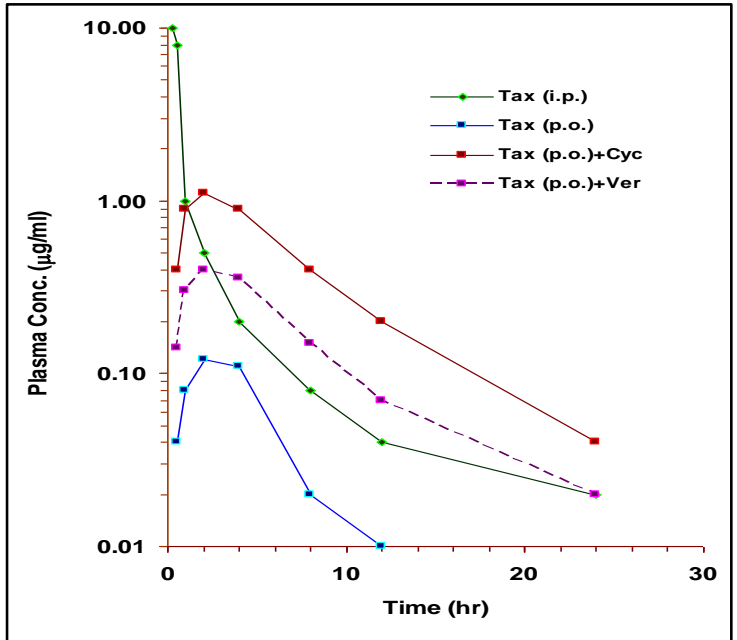

Figure 1: Plasma concentrations-time curve of paclitaxel with or without P-glycoprotein blockers in mice plasma. Each point represents the mean of six animals.

Effect of paclitaxel with or without p-glycoprotein blockers on p-glycoprotein activity in small intestine of mice

Since paclitaxel follows the same pathway as rhodamine-123, the degree of fluorescence in the intestine after giving the drug either orally or intraperitoneally did not differ from controls (Table 2). However, the co- organization of either cyclosporine or verapamil expanded the aggregation of rhodamine -123 (degree of fluorescence) into the intestine. Cyclosporine was more effective in that respect, as it increased in the fluorescence by (206.6 $\%$ ) compared to an increase of only (143.68\%) caused by verapamil (Table 2, Figure 2). 


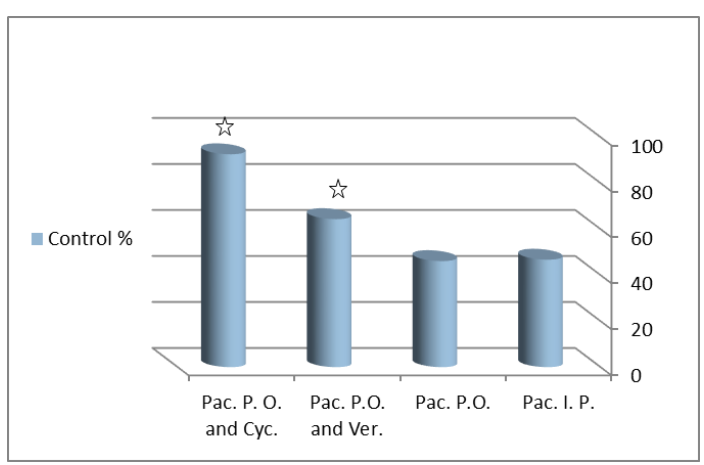

Figure 2: Effect of paclitaxel with or without Pglycoprotein blockers on P-glycoprotein activity in mice small intestine. Results are expressed as percentages of the mean control value.* Denote a significant difference.

Table 2: effect of paclitaxel with or without P-glycoprotein blockers on P-glycoprotein activity in small intestine of mice

\begin{tabular}{lc}
\hline Group & $\begin{array}{c}\text { Rhodamine-123 } \\
\text { fluorescence }(\mathbf{n g} / \mathbf{m l})\end{array}$ \\
\hline Control & $134.83 \pm 6.71$ \\
\hline Pac. i.p & $140.16 \pm 11.5$ \\
\hline Pac. P.o & $138.33 \pm 11.3$ \\
\hline Pac. P.o + Ver. & $193.08 \pm 4.8^{*}$ \\
\hline Pac. p.o + Cyc. & $277.66 \pm 14.5^{*}$ \\
\hline
\end{tabular}

Values are expressed as mean of six animals \pm SE. Asterisks denote a significant difference from control by using one way ANOVA followed by Duncan test at $\mathrm{p}<0.05$.

\subsection{Toxicological parameters of paclitaxel with or without P-glycoprotein blockers}

\subsubsection{Effect on total white blood cells count.}

Paclitaxel itself had no impact on the leukocytic check. Be that as it may, earlier organization of either cyclosporine or verapamil essentially diminished the full number of white blood cells at $24 \mathrm{hr}$ by $(60.6 \%)$ and $(78 \%)$ respectively. The effect of these agents was further worsen after $48 \mathrm{hr}$ reaching $(41 \%)$ for cyclosporine and $(53.3 \%)$ for verapamil (Table 3, Figure 3).

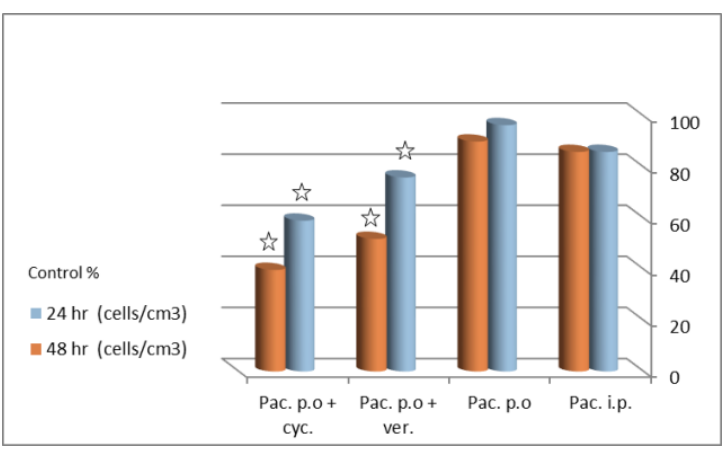

Figure 3: Effect of Paclitaxel with or without Pglycoprotein blockers on total white blood cells count in mice. Results are expressed as percentages of the mean control value.* Denote a significant difference.
Table 3: effect of paclitaxel with or without P-glycoprotein blockers on total white blood cells count in the whole blood of mice.

\begin{tabular}{|c|c|c|}
\hline Groups & $\begin{array}{c}24 \mathbf{h r} \\
\left(\text { cells/cm }{ }^{3}\right)\end{array}$ & $48 \mathrm{hr} \quad\left(\right.$ cells $\left./ \mathrm{cm}^{3}\right)$ \\
\hline Control & $6816.67 \pm 743.6$ & $6816.67 \pm 743.6$ \\
\hline Pac. i.p & $6016.67 \pm 769.6$ & $6016.67 \pm 936.81$ \\
\hline Pac. p.o & $6750 \pm 645.88$ & $6300 \pm 960.9$ \\
\hline $\begin{array}{l}\text { Pac } \\
\text { p.o + ver. }\end{array}$ & $5316.67 \pm 334.1 *$ & $3633.33 \pm 493.06 *$ \\
\hline $\begin{array}{l}\text { Pac. p.o + } \\
\text { cyc. }\end{array}$ & $4133.33 \pm 374.7 *$ & $2783.33 \pm 292.59$ * \\
\hline
\end{tabular}

Values are expressed as mean of six animals \pm SE. The Asterisks denote a significant difference from control by using one way ANOVA followed by Duncan test at $\mathrm{p}<0.05$. 3.2.2. Effect on $\mathrm{LDH}$ level in the serum of mice

The intraperitoneal injection of paclitaxel induced a two-fold increase in LDH levels after $24 \mathrm{hr}$ of administration. This effect was only transient, as it faded away $48 \mathrm{hr}$. The effect of oral administration of paclitaxel was not statistically significant from that of intraperitoneal injection. Co-administration of verapamil enhanced the LDH leakage to nearly 3-fold at $24 \mathrm{hr}$, but the effect was only transient, and tended to revert to normal after $48 \mathrm{hr}$. Cyclosporine, however, decreased the effect of paclitaxel on LDH leakage, such that there was only a (122\%) increase as compared to control values after $24 \mathrm{hr}$, an effect which was sustained after $48 \mathrm{hr}$ of administration (Table 4, Figure 4).

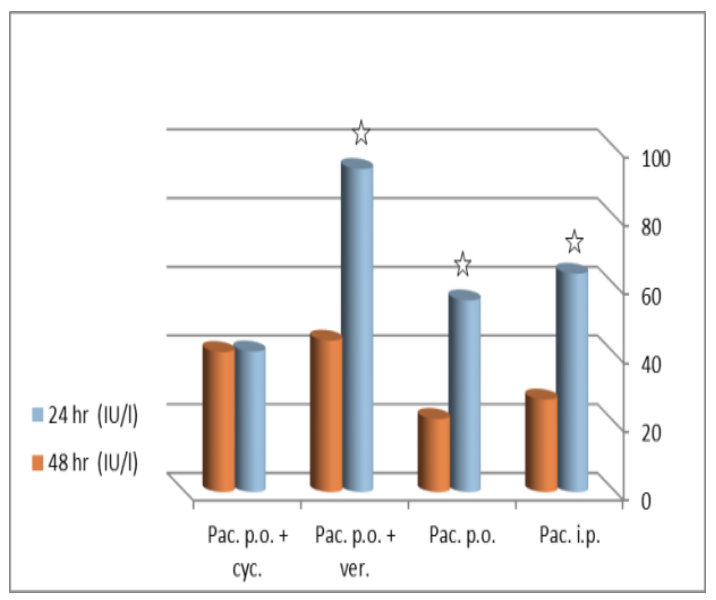

Figure 4: Effect of paclitaxel with or without Pglycoprotein blockers on LDH level in the serum of mice. Results are expressed as percentages of the mean control value.* Denote a significant difference. 
Table 4: effect of paclitaxel with or without p-glycoprotein blockers on LDH level in mice.

\begin{tabular}{|c|c|c|}
\hline Groups & $24 \mathrm{hr} \quad($ IU/l) & $48 \mathrm{hr} \quad$ (IU/l) \\
\hline Control & $335.67 \pm 39.6$ & $335.67 \pm 39.6$ \\
\hline Pac. i.p & $635.83 \pm 58.33 *$ & $269.67 \pm 9.31$ \\
\hline Pac. P.o & $558.33 \pm 36.27 *$ & $213 \pm 7.09$ \\
\hline $\begin{array}{c}\text { Pac. } \\
\text { p.o+ver. }\end{array}$ & $940.83 \pm 60.53 *$ & $441.17 \pm 30.89$ \\
\hline $\begin{array}{c}\text { Pac. } \\
\text { p.o+cyc. }\end{array}$ & $409.5 \pm 43.87$ & $408.33 \pm 16.56$ \\
\hline
\end{tabular}

Values are expressed as mean of six animals \pm SE. The Asterisks denote a significant difference from control by using one way ANOVA followed by Duncan test at $\mathrm{p}<$ 0.05 .

\subsubsection{Effect on cardiac CK-MB iso-enzyme in} serum of mice

Paclitaxel, given either intraperitoneally or orally, induced a marked rise in CK-MB activity after $24 \mathrm{hr}$ of administration, but the effect subsided after $48 \mathrm{hr}$. Prior administration of verapamil with oral paclitaxel augmented of intensified the cytotoxic effects of paclitaxel more than two-fold, an effect which was evidenced after $24 \mathrm{hr}$ as (1238\%), but subsided markedly after $48 \mathrm{hr}$, being only (321.2\%) of control. The prior administration of cyclosporine with paclitaxel also augmented the cytotoxic effect of the latter, but not to the same extent as verapamil, reaching (707\%) after $24 \mathrm{hr}$ and $(420 \%)$ after $48 \mathrm{hr}$ (Table 5 Figure 5).

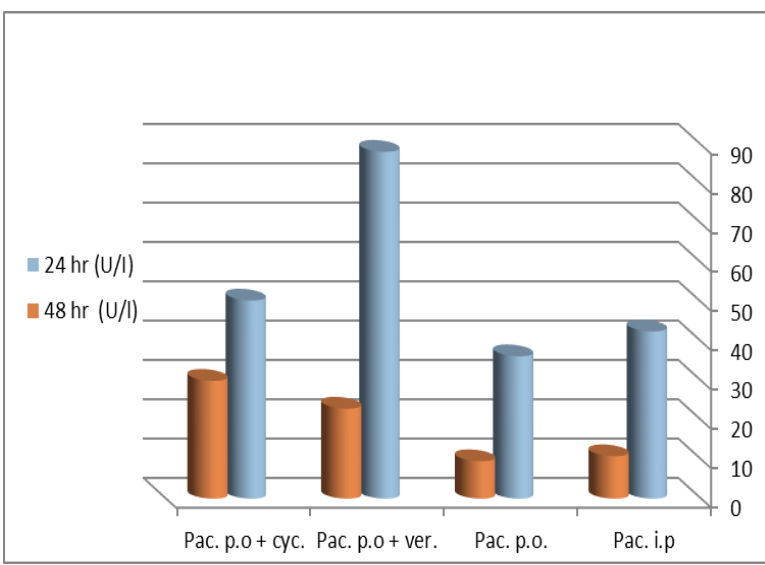

Figure 5: Effect of paclitaxel with or without Pglycoprotein blockers on the cardiac enzyme CK-MB in the serum of mice. Results are expressed as percentages of the mean control values. *Denote a significant difference.
Table 5: Effect of Paclitaxel with or without p-glycoprotein blockers on CK-MB in mice serum.

\begin{tabular}{lll}
\hline Groups & $\mathbf{2 4} \mathbf{~ h r}(\mathbf{U} / \mathbf{l})$ & $\mathbf{4 8} \mathbf{~ h r}(\mathbf{U} / \mathbf{l})$ \\
\hline Control & $213.83 \pm 8.41$ & $213.83 \pm 8.41$ \\
\hline Pac. i.p & $1276.17 \pm 65.74 *$ & $323.67 \pm 40.87$ \\
\hline Pac. p.o & $1087 \pm 93.44^{*}$ & $285.67 \pm 49.06$ \\
\hline $\begin{array}{l}\text { Pac. p.o }+ \\
\text { ver. }\end{array}$ & $2647 \pm 299.97 *$ & $687 \pm 60.24 *$ \\
\hline $\begin{array}{l}\text { Pac. p.o }+ \\
\text { cyc. }\end{array}$ & $1511.67 \pm 160.39^{*}$ & $899.17 \pm 26.23^{*}$ \\
\hline
\end{tabular}

Values are expressed as mean of six animals \pm SE. The Asterisks denote a significant difference from control by using one way ANOVA followed by Duncan test at $\mathrm{p}<0.05$.

\subsubsection{Histopathological examinations}

The histopathological studies were carried in the Pathology Department of the National Cancer Institute of Egypt. The hearts of mice treated with oral paclitaxel revealed only minimal interfascicular oedema and mild focal lymphocytic infiltration (Figure 6A and B). Animals treated with intraperitoneal Paclitaxel showed marked diffuse interfascicular oedema, inflammatory exudate with collections of histocytes, and focal feathery degeneration of myocardial cells (Figure 6C and D). Treatment with paclitaxel orally in the presence of $\mathrm{P}$ glycoprotein blockers (cyclosporine or verapamil) was accompanied by significant pathological changes with moderate to marked interfascicular edema, focal inflammatory aggregates, and subendothelial collection of histocytes (Figure $6 \mathbf{E}$ and $\mathbf{F}$ ).

Effect of P-gp blockers on antitumor activity of paclitaxel in mice bearing solid Ehrlich Carcinoma

Intraperitoneal administration of paclitaxel induced a prominent antitumor effect, whereas oral administration of paclitaxel had no effect (Figure 7). Prior administration of cyclosporine with paclitaxel barely enhanced the anticancer activity of oral paclitaxel. On the other hand, using cyclosporine pretreatment induced 4.3 days delay of the tumor growth as regard to control of $2500 \mathrm{~mm}^{3}$. Prior administration of verapamil with paclitaxel showed no effect. The percentage inhibition of tumor growth compared to control group at various time intervals (2, 10, 16, 22 \& 28 days) after Ehrlich carcinoma inoculation, was represented in (Table 6, Figure 7). 
A.

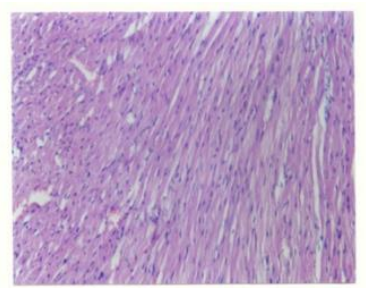

C.

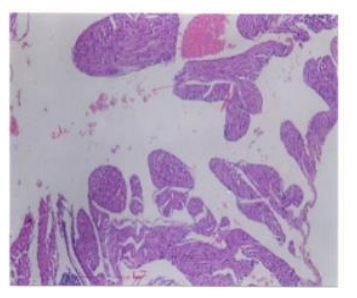

E.

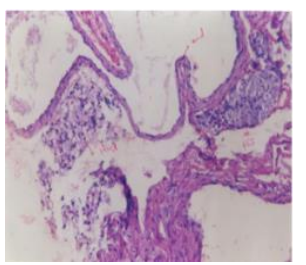

B.

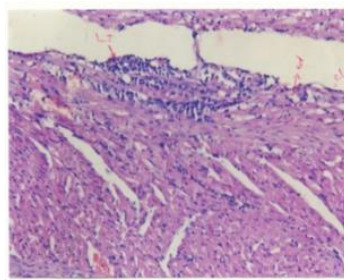

D.

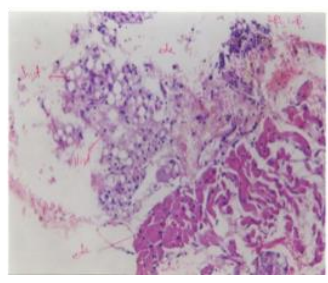

F.

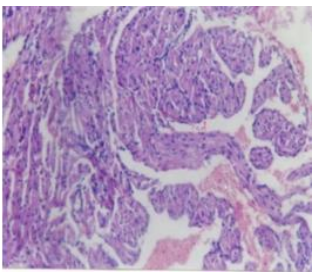

Figure 6: Histological examination of the heart of a control mouse showing normal myocardial histology (H \& E x 200) [A]. Histological examination of the heart of a mouse treated with oral paclitaxel showing minimal edema and mild focal lymphocytic cell infiltrate (H \& E, x 200) [B]. Section of the heart of a mouse treated with intraperitoneal paclitaxel showing marked diffuse interfascicular edema $(\mathrm{H}$ $\&$ E, x 100) [C]. Section of a heart of mouse treated with intraperitoneal paclitaxel showing marked interstitial edema and large collections of histocytes (H \& E x 200) [D]. Section of a heart of mouse treated with oral paclitaxel and cyclosporin showing moderate interstitial edema $(\mathrm{H} \&$ E, $x$ 200) [E]. Section of a heart of mouse treated with oral paclitaxel and cyclosporin showing subendothelial collections of histocytes (H \& E, x 200) [F].

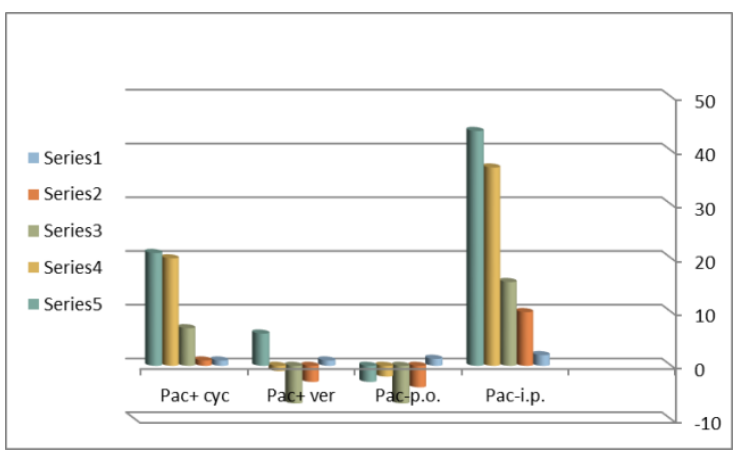

Figure 7: Percentage inhibition of tumor growth of solid Ehrlich carcinoma compared to control group in tumor

bearing mice after treatment with paclitaxel alone or in combination with either verapamil or cyclosporine. Results presented as percentage inhibition of the tumor growth as compared to control at days $2,10,16,22$ and 28 . * indicates a significant change $v s$ control $(\mathrm{p}<0.05)$ using Student's unpaired t-test.

Table 6: the effect of drug treatment on percentage inhibition of tumor growth in Ehrlich ascites carcinoma bearing mice.

\begin{tabular}{ccccc}
\hline Days after & \multicolumn{4}{c}{ \% inhibition of growth } \\
\cline { 2 - 5 } $\begin{array}{c}\text { tumor } \\
\text { inoculation }\end{array}$ & Pac-i.p & Pac-p.o & Pac+ ver & Pac+ cyc \\
\hline 2 & $2 \%$ & $1.3 \%$ & $1 \%$ & $1 \%$ \\
\hline 10 & $10 \%$ & $-4 \%$ & $-3 \%$ & $1 \%$ \\
\hline 16 & $15.6 \%$ & $-7 \%$ & $-7 \%$ & $7 \%$ \\
\hline 22 & $36.9 \%$ & $-2 \%$ & $-1 \%$ & $20 \%$ \\
\hline 28 & $43.7 \%$ & $-3 \%$ & $6 \%$ & $21 \%$ \\
\hline
\end{tabular}

$\%$ inhibitions calculated with respect to control untreated animals, where the tumor volume was $100 \mathrm{~mm}^{3}$

\section{DISCUSSION}

Paclitaxel has been utilized for distinctive sorts of cancer, counting breast, lung, ovarian and liver cancer ${ }^{17}$. Paclitaxel is managed intravenously; this course is related some of the time with extreme clinical side impacts influencing the cardiovascular and apprehensive frameworks ${ }^{18}$. The destitute verbal bioavailability of paclitaxel is due, at slightest in portion, to restraint of assimilation by the P-gp efflux pump within the intestinal mucosa, and/or to the digestion system by cytochrome P450 (CYP 3A) in both the liver and epithelial cells of the little digestive tract $^{19}$. Within the current consider paclitaxel was decided quantitatively by HPLC examination in arrange to ponder the impact of P-gp blockers (cyclosporine \& verapamil) on the verbal bioavailability of paclitaxel. The pre-treatment of the creatures with P-gp blockers uniquely expanded the verbal AUC, recommending that the increment is at slightest somewhat due to hindrance of the P-gp efflux pump, hence permitting for superior assimilation of paclitaxel. The expanded systemic level of the sedate may have to come about from the impedances of these specialists with the paclitaxel end pathway. The upgraded bioavailability of paclitaxel by pretreatment with verapamil may be ascribed moreover, to both the restraint of cytochrome P-450 (CYP3A4) and the P-gp efflux pump within the liver and intestinal mucosa ${ }^{20}$.

Cyclosporine is considered a better reverser of P-gp than verapamil as shown in the present study, possibly due to its higher affinity for P-gp binding surface and its great ability to inhibit ATPase activity, thus allowing for the free influx of paclitaxel ${ }^{21}$. This might also explain the higher AUC found in oral 
paclitaxel group pretreated with cyclosporine compared to the group pretreated with verapamil.

Animals treated with paclitaxel alone (whether oral or parenteral) showed no Rh 123 accumulation in the intestinal cells, whereas those treated with either cyclosporine or verapamil showed marked accumulation, particularly in animals treated with the former. The accumulation of the dye is due to a decrease in P-gp function through blocking its activity with the P-gp blockers. The enhancement of oral paclitaxel bioavailability by pretreatment with the Pgp blockers, cyclosporine and/or verapamil, may carry the additional risk of increasing its undesirable side effects. It would therefore be necessary to adjust the dose of the drug by continuous monitoring during treatment. The present findings showed that paclitaxel administered orally or intraperitoneally had no effect on the white cell count when given alone. However, concomitant administration of either cyclosporine or verapamil led to a significant decrease in WBC count, the effect of cyclosporine being more marked. However, that fact does not rule out the possibility that the increased myelosuppression could be also partly associated with the P-gp blocking effect of the drug. Biochemically, verapamil pre-treatment induced a marked increase in serum creatine phosphokinase (CK-MB) and lactate dehydrogenase (LDH) activity, particularly evident after 24 hours of administration. The rise in the level of these enzymes seems to have been only transient, as the level tended to revert to normal values after 48 hours. However, cyclosporine does not apparently affect the heart to a great extent in the doses used in this study, when combined with paclitaxel. Cyclosporine augmented paclitaxel effect on CK-MB, indicating that this observation may have been associated with the higher bioavailability of the drug. However, this higher bioavailability seems not to have influenced the effect of paclitaxel on serum LDH levels.

\section{CONCLUSIONS}

An important issue resulting from this work is the development of a simplified method of extraction of paclitaxel from plasma samples, which could eventually be applicable for the routine monitoring of the drug in patients being treated with Paclitaxel. The oral bioavailability of paclitaxel was enhanced 2.7 fold by verapamil, and up to 5.7 fold by cyclosporine, showing that both drugs effectively inhibited the P-gp pump in the intestinal tract of mice. Cyclosporine has higher P-gp blocking activity and oral bioavailability of paclitaxel more than verapamil. It is worth to mention that, combination of cyclosporine / verapamil with paclitaxel does not affect the antitumor activity. Furthermore, the enhanced absorption of paclitaxel does not aggravate its toxicity. However, pretreatment with verapamil worsens the toxic cardiac effects of paclitaxel.

Ethics Approval and Consent to Participate: The study was done according to the NCI and Pharmaceutical animal ethics regarding to the international rules.

Human and Animal Rights: Animals were used for studies that are base of this research.

Consent for Publication: Not applicable.

Conflict of Interest: The authors declare no conflict of interest, financial or otherwise.

Acknowledgements: The authors are grateful to all members of the cell culture lab, faculty of pharmacy, Al-Azhar University (Girls) for carrying out the antitumor activity.

Authors' contribution: All authors work equally in this paper in the practical and written work.

\section{References}

1. Stage TB, Bergmann TK, Kroetz DL. Clinical Pharmacokinetics of Paclitaxel Monotherapy: An Updated Literature Review. Clin Pharmacokinet. 2018;57(1):7-19.

2. Bharadwaj R, Yu H. The spindle checkpoint, aneuploidy, and cancer. Oncogene. 2004;23(11 REV. ISS. 1):2016-27.

3. He Y, Yan D, Zheng D,Hu Z, Li H, Li J. Cell Division Cycle 6 Promotes Mitotic Slippage and Contributes to Drug Resistance in PaclitaxelTreated Cancer Cells. PLoS ONE. 2016; 11(9):e0162633.

doi.org/10.1371/journal.pone.0162633.

4. Chiang PC, Gould S, Nannini M, Qin A, Deng Y, Arrazate A, Kam K, Ran Y, Wong H. Nanosuspension delivery of paclitaxel to xenograft mice can alter drug disposition and anti-tumor activity. Nanoscale research letters. 2014; 9(1):156.

5. Torne SJ, Ansari KA, Vavia PR, Trotta F, Cavalli R.Enhanced oral paclitaxel bioavailability after administration of paclitaxel loaded nanosponges. Drug Delivery. 2010; 17 (6): 419-425.

6. Amin ML. P-glycoprotein inhibition for optimal drug delivery. Drug Target Insights. 2013; 2013(7):27-34

7. Gupta SK, Singh P, Ali V, Verma M. Role of membrane-embedded drug efflux ABC transporters in the cancer chemotherapy. Oncol Rev. 2020;14(2):448-53. 
8. Callaghan R, Luk F, Bebawy M. Inhibition of the multidrug resistance P-glycoprotein: time for a change of strategy. Drug metabolism and disposition: the biological fate of chemicals. 2014;42(4): 623-631.

9. Hamed AR, Abdel-Azim NS, Shams KA, Hammouda FM. Targeting multidrug resistance in cancer by natural chemosensitizers. Bull Natl Res Cent. 2019; 43(8).

10. Ozols RF, Cunnion RE, Klecker RW, Hamilton TC, Ostchega Y, Parrillo JE, et al. Verapamil and Adriamycin in the Treatment of Drug-Resistant Ovarian Cancer Patients Calcium antagonists are one of the group of had studied its effect on the cytotoxicity of Adriamycin in human ovarian cancer cell lines with primary resistance induced to. J Clin Oncol. 2014;5(4):641-7.

11.Li Y, Li N, Yu X, Huang K, Zheng T, Cheng X, et al. Hematoxylin and eosin staining of intact tissues via delipidation and ultrasound. Sci Rep. 2018; 8(1):1-8.

12. Xia XJ, Peng J, Zhang PX, Jin DJ, Liu YL. Validated HPLC Method for the Determination of Paclitaxel-related Substances in an Intravenous Emulsion Loaded with a PaclitaxelCholesterol Complex. Indian J Pharm Sci. 2013 Nov;75(6):672-9.

13. Ludescher C, Thaler J, Drach D, Drach J, Spitaler M, Gattringer C, et al. Detection of activity of Pglycoprotein in human tumour samples using rhodamine 123. Br J Haematol. 1992;82(1):1618 .

14. Chanarin I. Laboratory haematology: an account of laboratory techniques. Churchill Livingstone; 1989.

15. Wu AH, Bowers GN Jr. Evaluation and comparison of immunoinhibition and immunoprecipitation methods for differentiating $\mathrm{MB}$ and $\mathrm{BB}$ from macro forms of creatine kinase isoenzymes in patients and healthy individuals. Clin Chem. 1982 Oct;28(10):2017-21.

16. Papadopoulos D, Kimler BF, Estes NC, Durham FJ. Growth delay effect of combined interstitial hyperthermia and brachytherapy in a rat solid tumor model. Anticancer research. 1989;9(1):45.

17. Priyadarshini K.and Keerthi U. Paclitaxel Against Cancer: A Short Review. Medicinal Chemistry. 2012; 02(07): 139-141.
18. Alqahtani, F. Y.; Aleanizy, F. S.; El Tahir, E.; Alkahtani, H. M.; AlQuadeib, B. T. Chapter Three - Paclitaxel; Brittain Excipients and Related Methodology, H. G. B. T.-P. of D. S., Ed.; Academic Press, 2019; 44: 205-238.

19. Pooja D, Kulhari H, Kuncha M, Rachamalla SS, Adams DJ, Bansal V, Sistla R. Improving Efficacy, Oral Bioavailability, and Delivery of Paclitaxel Using Protein-Grafted Solid Lipid Nanoparticles. Mol Pharm. 2016; 13(11):39033912.

20. Ondieki G, Nyagblordzro M, Kikete S, Liang R, Wang L, He X. Cytochrome P450 and PGlycoprotein-Mediated Interactions Involving African Herbs Indicated for Common Noncommunicable Diseases. Evid Based Complement Alternat Med. 2017;2017: 2582463.

21. Teodori E, Braconi L, Bua S, Lapucci A, Bartolucci G, Manetti D, Romanelli MN, Dei S, Supuran CT, Coronnello M. Dual PGlycoprotein and CA XII Inhibitors: A New Strategy to Reverse the P-gp Mediated Multidrug Resistance (MDR) in Cancer Cells. Molecules. 2020;25(7):1748. 